\title{
THE STRATIGRAPHIC POSITION OF A PLIOCENE TIDAL CLAY DEPOSIT AT GROBBENDONK (ANTWERP PROVINCE, BELGIUM)
}

\author{
Noël VANDENBERGHE ${ }^{1}$, Jacques HERMAN², Pieter LAGA², Stephen LOUWYE ${ }^{3}$, Stijn DE \\ SCHEPPER $^{3}$, Jef VANDENBERGHE ${ }^{4}$, Sjoerd BOHNCKE ${ }^{4} \&$ Martin KONERT $^{4}$
}

(5 figures \& 4 photographs)

\author{
1 Historische Geologie, K.U.Leuven, Belgium \\ 2 Belgische Geologische Dienst, Brussel, Belgium \\ 3 Onderzoekseenheid Paleontologie, U.Gent, Belgium \\ 4 Aardwetenschappen, V.U.Amsterdam, The Netherlands
}

\begin{abstract}
In a section located in Grobbendonk (Antwerp Campine area, Belgium) a tidal clay deposit is described which according to regional analysis could correlate with the Kruisschans Member of the Pliocene Lillo Formation. Mollusc and fish fossils point to a colder climate during the deposition of the Kruisschans Sand. A pollen analysis of the Grobbendonk clay shows that it was formed during a cold climate, either during the Pretiglian or during the Pliocene. The latter possibility is preferred because of the regional stratigraphic analysis and the absence of marine Pretiglian in the area. A dinoflagellate study of the Grobbendonk clay compares the stratigraphic position of the clay to the Waltonian, Pre-Ludhamian, Ludhamian regional stages of the U.K. Because of the cold climate during the deposition a PreLudhamian formation time is preferred. This Pre-Ludhamian in the U.K. is correlated with the Reuver C or with the Praetiglian regional stages in the Netherlands.
\end{abstract}

KEYWORDS: Pliocene, Belgium, stratigraphy, pollen, dinoflagellates

\section{Introduction}

In 1997 excavation works for a water recharge installation had started on the production site of the drinking water company PIDPA in Grobbendonk, located in the Antwerp province, Belgium (Fig.1). The excavation was made in order to reach the permeable Diest Sand Formation (Upper Miocene). The idea for a recharge installation at this location has a longer history and some of the earlier studies have tried to use a localised PlioPleistocene sand body incising from the surface into the Diest Sand (De Rycker, 1982). This sand body underlies the Pleistocene eolian sand cover. It was first identified by Halet (1938, layer C on fig.2) and its presence was later confirmed by Laga (1976). It is represented on the newly published 1:50 000 geological map as an incision filled with Brasschaat Sand, although the normal outcrop zone of this Brasschaat Sand unit occurs more northwards (Schiltz et al. 1993, profile 4 29E/201). This sand is incising into the Diest Sand and it is partially cemented by phosphate, especially in the lower part. The maximal incision observed in boreholes is up to $15 \mathrm{~m}$, reaching the level of -5 m TAW, requiring an exceptionally low erosion base at that time.

In the 1997 excavation, the top meters of the section expose a continuous tidally deposited clay unit (Photo 1).
Although this clay unit was recognised on the same site by Halet (1938) as layer E on his fig.2 and by Laga (1976), the clay unit is very seldom exposed and its sedimentological facies is unlike other lithostratigraphical units recognised in the area. Therefore a more careful examination was justified.

\section{The lithological section and the stratigraphic constraints}

The base of the excavation is located well within the Diest Sand Formation (unit 1 on Fig.1). The sands are medium grained, contain abundant glauconite, consist of poorly rounded grains and display horizons with oblique stratification and with intense bioturbation by worms. Louwye et al. (1999) determined in a nearby well in Poederlee dinoflagellate zonation DN9 of de Verteuil and Norris (1996) for most of the Diest Sand Formation except for its top which is situated in the DN 10 biozone. The former biozone characterises Upper Tortonian sediments whilst the latter characterises uppermost Tortonian and Lower to Middle Messinian sediments.

The Diest Sand is overlain by about half a meter of coarse sand containing some sparse small pebbles (Photo 2) (unit 2 on Figure 1). The base of this sand unit consists of a 


\section{$+9.10 \mathrm{~m}$ TAW}

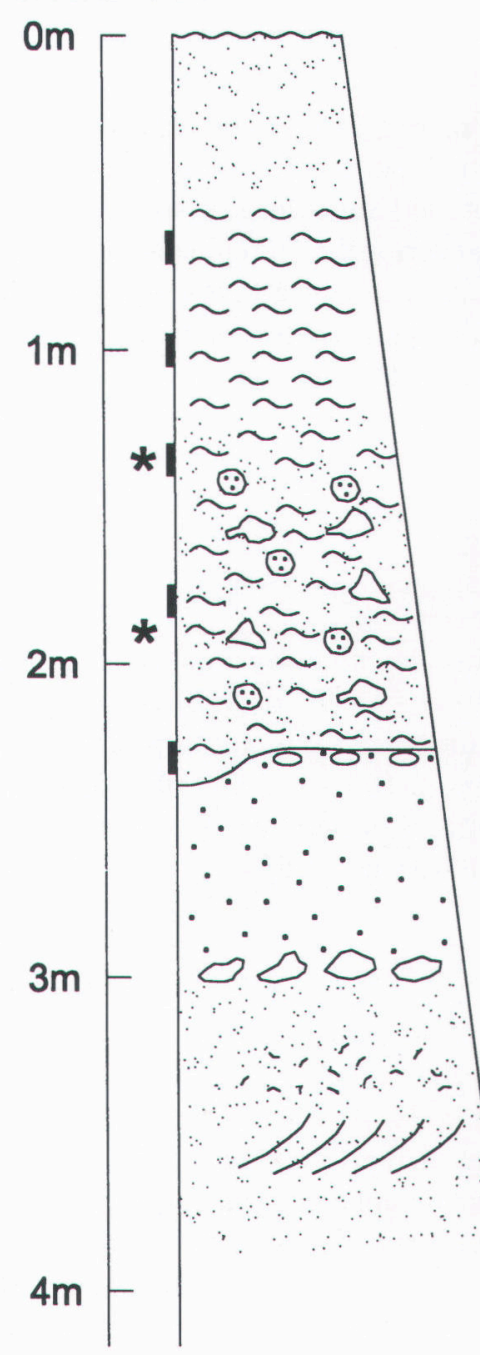

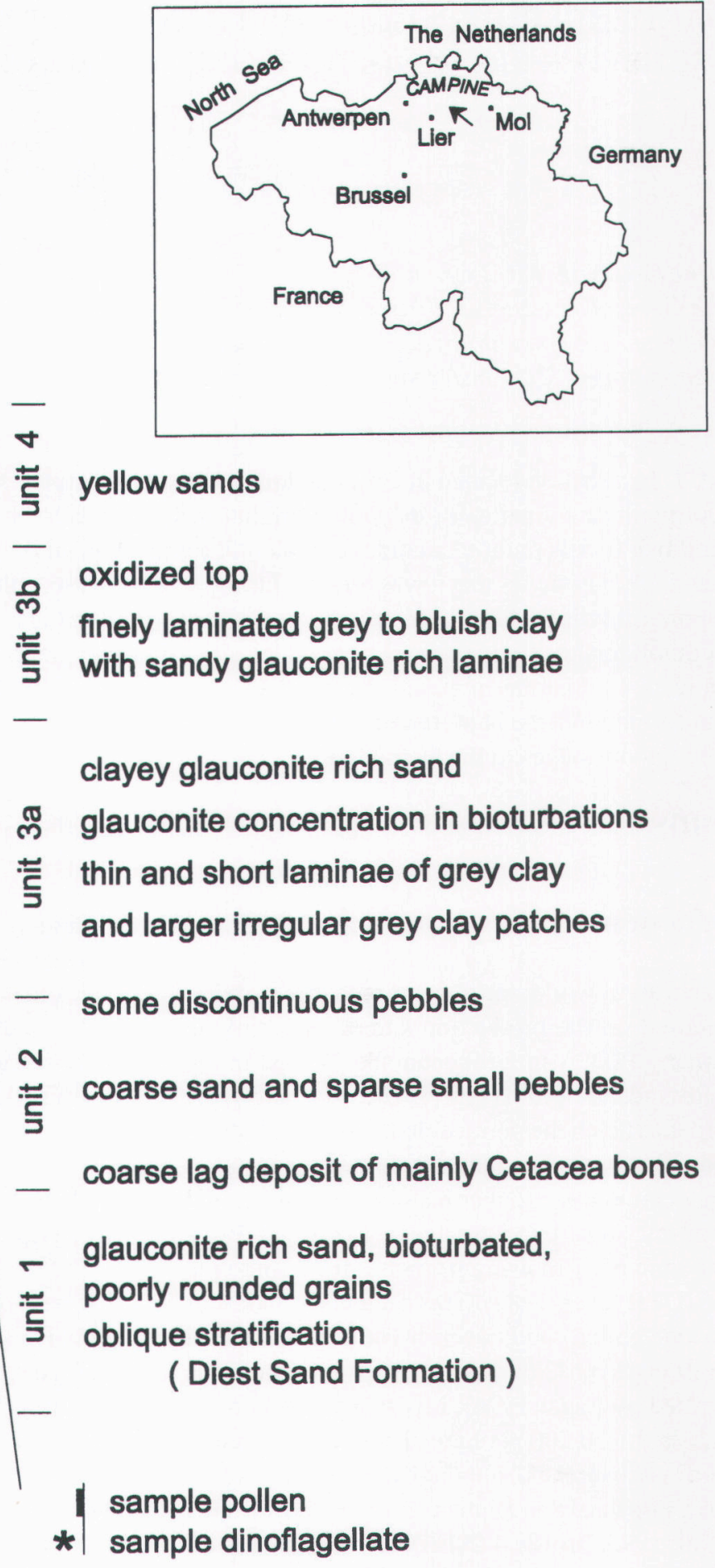

Figure 1. General situation map and the discussed lithological section at the Grobbendonk site (located at the arrow on the inset). 

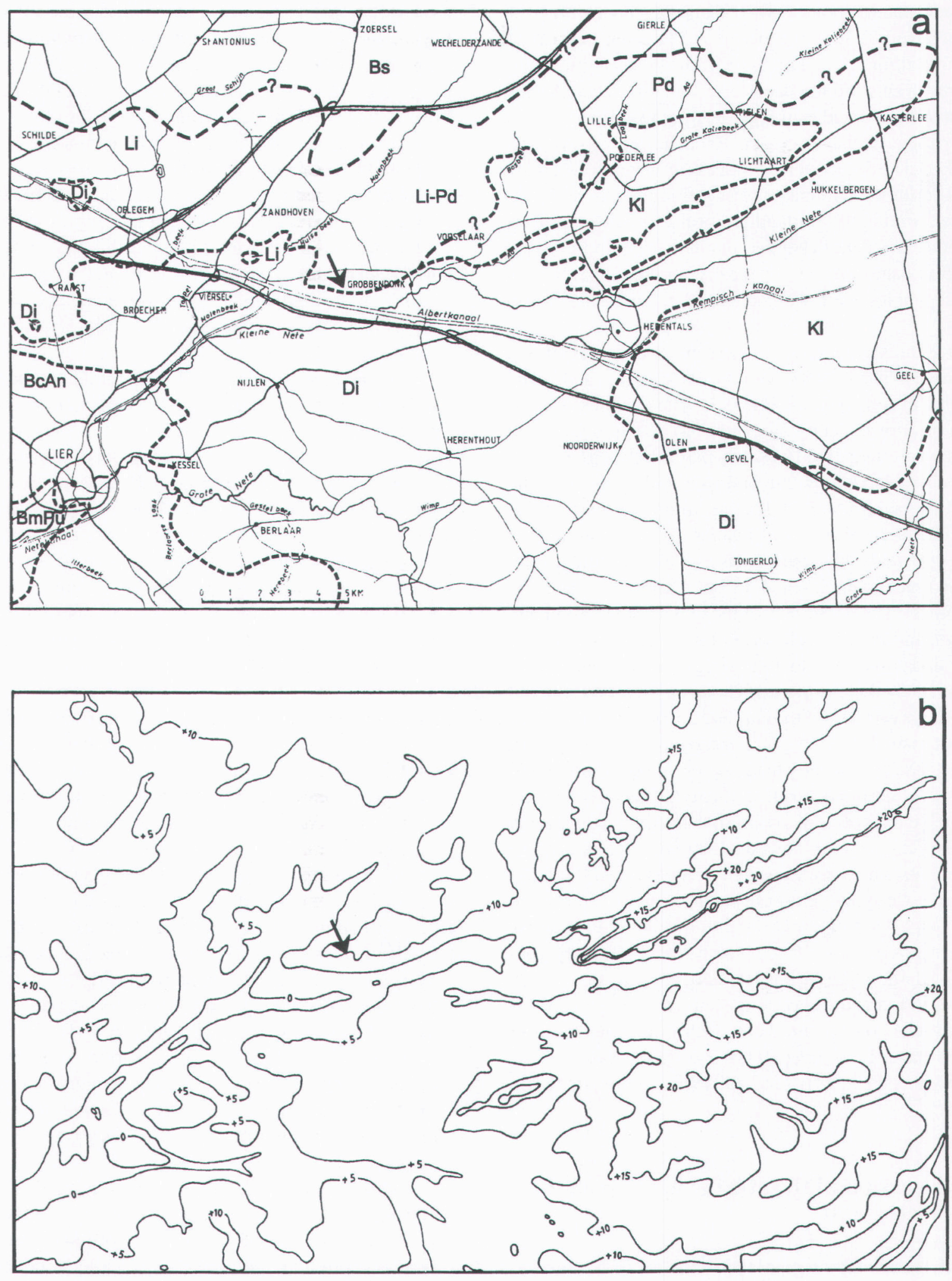

Figure 2. (a) A geographical map of the area studied with the extension of the mapped geological units (hatched lines) ; Bs : Brasschaat Formation; Li : Lillo Formation; Di : Diest sand Formation; Pd : Poederlee Formation ; Kl : Kasterlee Formation ; BcAn :Antwerpen Sand Member of the Berchem Formation; BmPu : the Putte Clay Member of the Boom Clay Formation (see stratigraphic position on Figure 5 ). The arrow indicates the location of the studied profile.

(b) An isohypse map of the top of the Tertiary in the same area as shown on Figure 2a. The arrow indicates the location of the studied profile. 
lag deposit in which the most prominent fragments are large Cetacean bones. Such Cetacean bones are well known from different Miocene and Pliocene deposits in North Belgium. The large size of the bones requires that the reworking did not occur over long distances. A fragment of a cemented pogonophore trace fossil in the coarse layer suggests that also some Pliocene deposits were reworked. The dinoflagellate cyst assemblages found in the sand during a preliminary investigation compare well with those found in the Kattendijk Formation in the Antwerp harbour area (De Schepper, unpublished). In the top of the thin sand unit occurs locally another horizon with small pebbles and reworked fossils (i.a. pectenid shells).

Above the sand unit occurs the clay deposit (unit 3 of Figure 1). The contact with the underlying sand seems erosive in some places (Photo 2). The clay deposit consists of a lower sandy part (unit 3a) and an upper more clayey part (unit 3b). The sandy part is rich in glauconite. It is characterised by thin and short pale gray pure clay laminae dispersed in the sediment and by larger centimeter-sized irregular patches of the same type of pale gray pure clay. The sand is also bioturbated by large worm tracks which show an enrichment in glauconite (Photo 3). The upper part of the clay is finely laminated (wavy, millimetre scale). It is bluish grey turning pale grey and rusty on oxidation, suggesting the presence of some finely divided pyrite (Photo 4). Small erosive features have carved into the clay and coarse laminated sands are deposited in such small erosive pockets $(\mathrm{cm}$ to $\mathrm{dm}$ scale). The sedimentary features described point to a shallow tidal marine deposit, probably a tidal flat environment. No macrofossils are present and the age of the clay deposit can only be bracketed between the underlying sediments which are Lower Pliocene (Kattendijk Sand) and the overlying yellowish sands at the top of the section (unit 4 of Figure 1) which are latest Pleistocene coversands (see also Vandenberghe 1983). Slightly to the north of the studied profile, between the base of the coversands and the clay unit, occurs a pale coloured fine clayey glauconitic sand layer with iron cemented fragments (layer D of Halet 1938) also eroded locally by the deeply incising quartz sand gully (not studied in this paper).

\section{Discussion of the stratigraphic position of the clay unit}

\subsection{A regional geological approach}

Reading the top Tertiary relief and the regional geological maps (Schiltz et al. 1993 and Fig.2a and 2b) it can be seen that the site of the excavation is located on the northern slope of a broad valley incised in the top of the Tertiary (which for practical reasons is defined here as the top of the Lillo, Poederlee and Brasschaat Formations). The erosional valley coincides with the present Kleine Nete river valley. At the top of the slope appear the Pliocene Poederlee-Lillo Formations, difficult to distinguish from each other in the area. Very nearby the area, at about the same level, also occurs the western termination of the Lower Pliocene Kasterlee Formation (Fig.2a). If the clay deposit would unconformably overly the Pliocene deposits it would therefore be deposited in the broad erosional valley and needed to be very young, namely formed after the main geomorphological sculpturing of the area. As the deposit is a marine sediment this has to be excluded and therefore it must be older than the last marine deposits in the area which are of Tiglian age (Campine Clay) (Fig.5). Younger interglacial estuarine deposits are only known from West Belgium (Tavernier \& De Moor 1974, Paepe \& Van Hoorne 1976). It can neither be correlated with the Campine Clay itself to which the lithology resembles most. Indeed, although this clayey tidal flat deposit of Tiglian age (see Kasse 1988) occurs slightly more northwards, its outcrop zone there occurs at a distinctly higher topographic level while it is dipping northwards (Gulinck 1962). Therefore for geometrical reasons, no correlation with the Campine clay can be assumed. And as the clay unit at Grobbendonk cannot unconformably overly older deposits it can be concluded that geometrically the clay unit must belong to the series of conformable Late Miocene and Pliocene deposits.

In the section of Halet (1938) a clay unit (E) is occurring at this site between about +5 and $7 \mathrm{~m}$ T.A.W. level. There is little doubt therefore that the same clay unit as observed in the new excavation (unit 3 of Fig. 1) is involved (see levels in Fig.1). Halet's section assumes that this clay unit is conformably intercalated between the Diest Formation and the Poederlee-Lillo Formations, as also discussed and concluded above, and that it is part of the Lillo Formation. In Halet's section the coarse sand with fossil bone fragments of Fig. 1 is interpreted as the coastal sand layer belonging to and underlying the clay unit 3. A fossiliferous, fine clayey and glauconite containing sand is described on top of the clay unit (his unit D). The fossils in these overlying sands are described only in one location by Halet and in an iron cemented sandstone (Halet 1938, p.571 Cardium decorticatum, Cardium edule, Cyprina islandica, Pecten opercularis).

Reviewing the regional Pliocene geology of the area, Buffel et al. (2001) concluded that an iron cemented stone layer with fossil moulds reported by different authors probably represents the same correlatable stone level; Gulinck (1962) reports such a regionally occurring sandstone layer near the base of the 'sands with Corbula'; Buffel et al. (2001) describe to the southwest of Turnhout an iron stone layer with fossil moulds overlying pebbles at the base of the Poederlee Sand (a Campine Pliocene lithostratigraphical unit (Figs.2a,5)); Geets (1962) studied the stone layer about 4 to $5 \mathrm{~m}$ above the base of the 


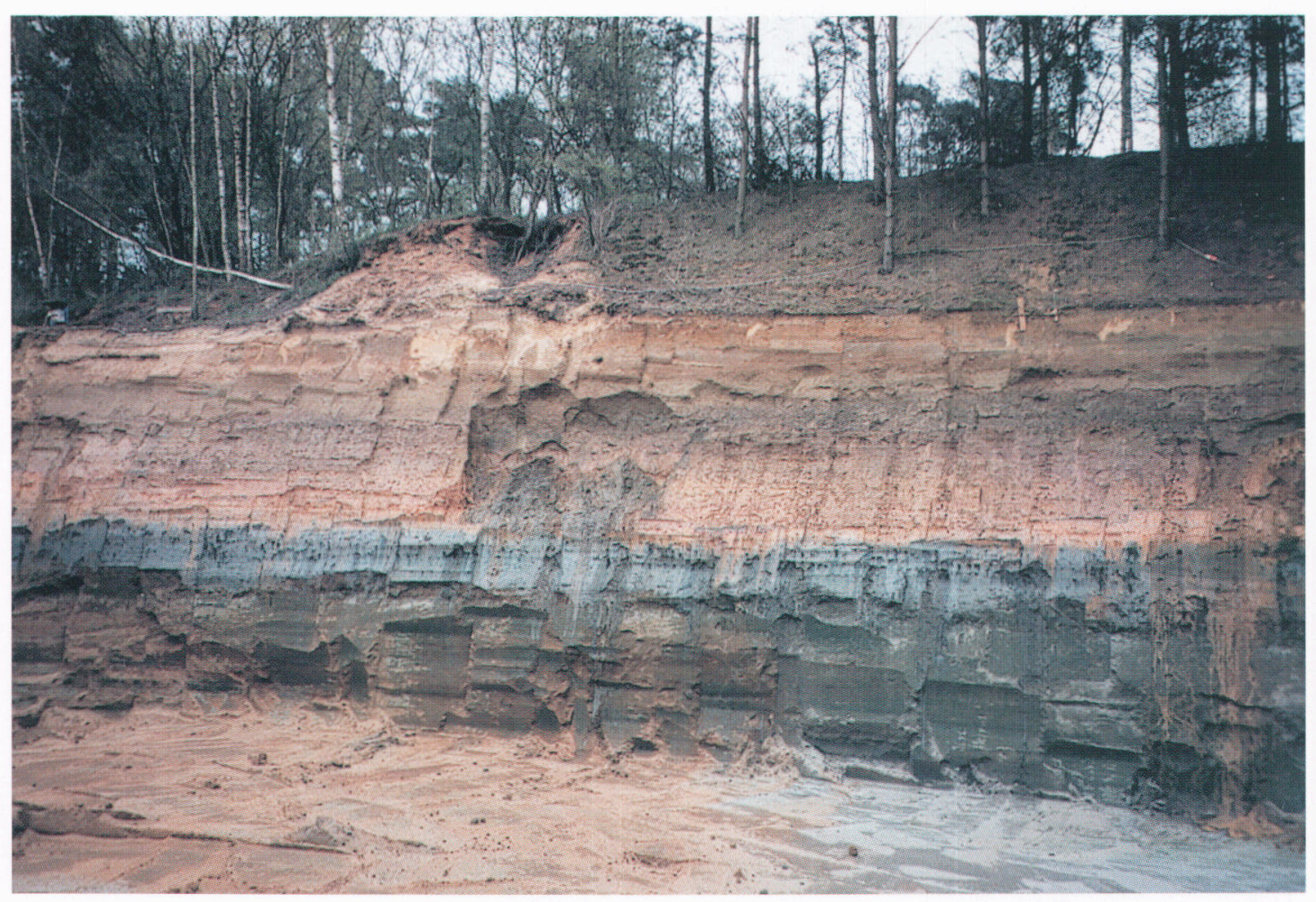

Photograph 1. Overview of the section in Grobbendonk. The clay layer discussed in the paper is the marked bluish grey horizon.

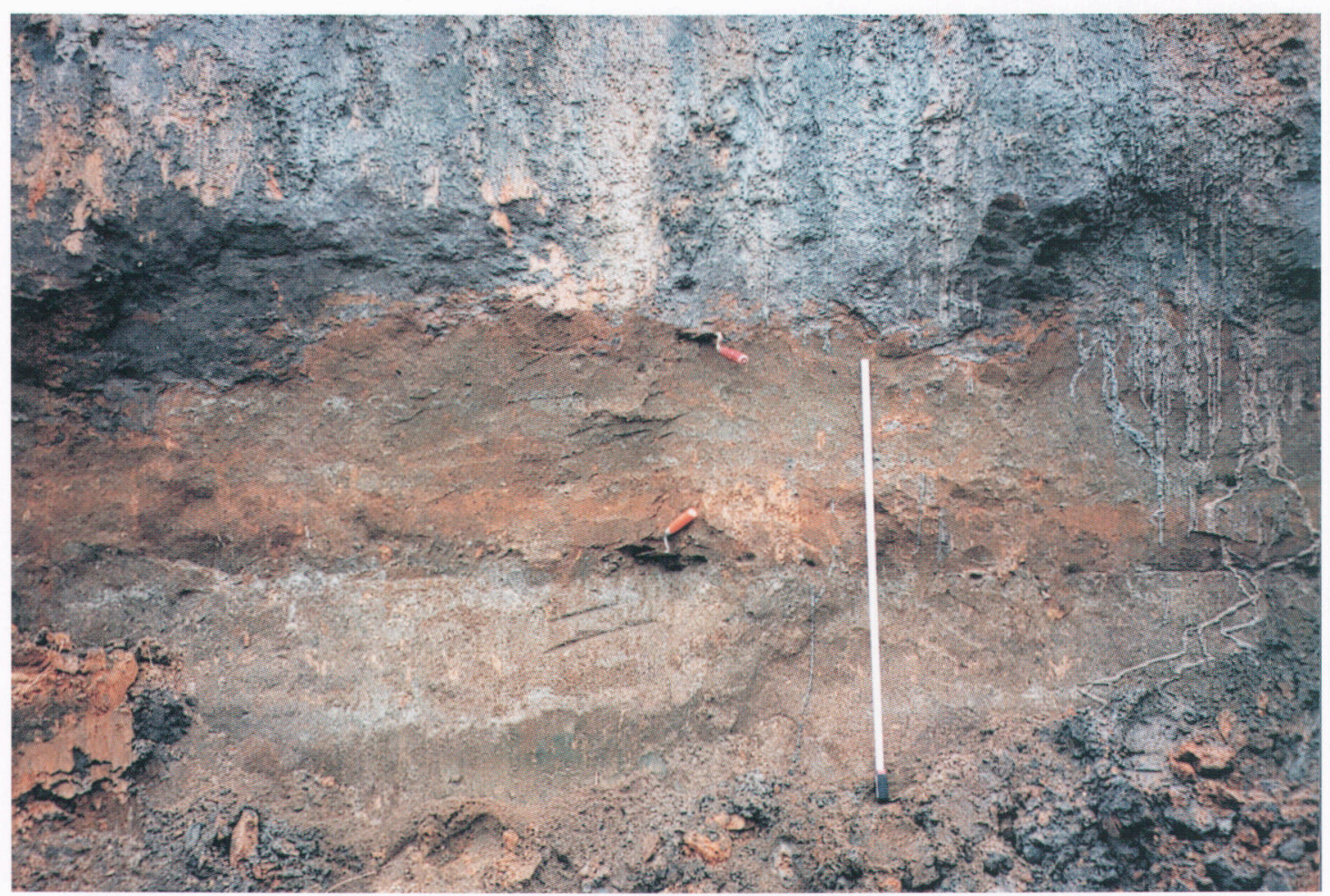

Photograph 2. The limonite stained sand layer in the middle of the photograph is unit 2 of Figure 1. It occurs between the Diest Sand below (base of the photograph) and the bluish clay deposit above. Note the irregular upper contact of the sand with the bluish clay and also some larger fragments at the base of the sand layer. 


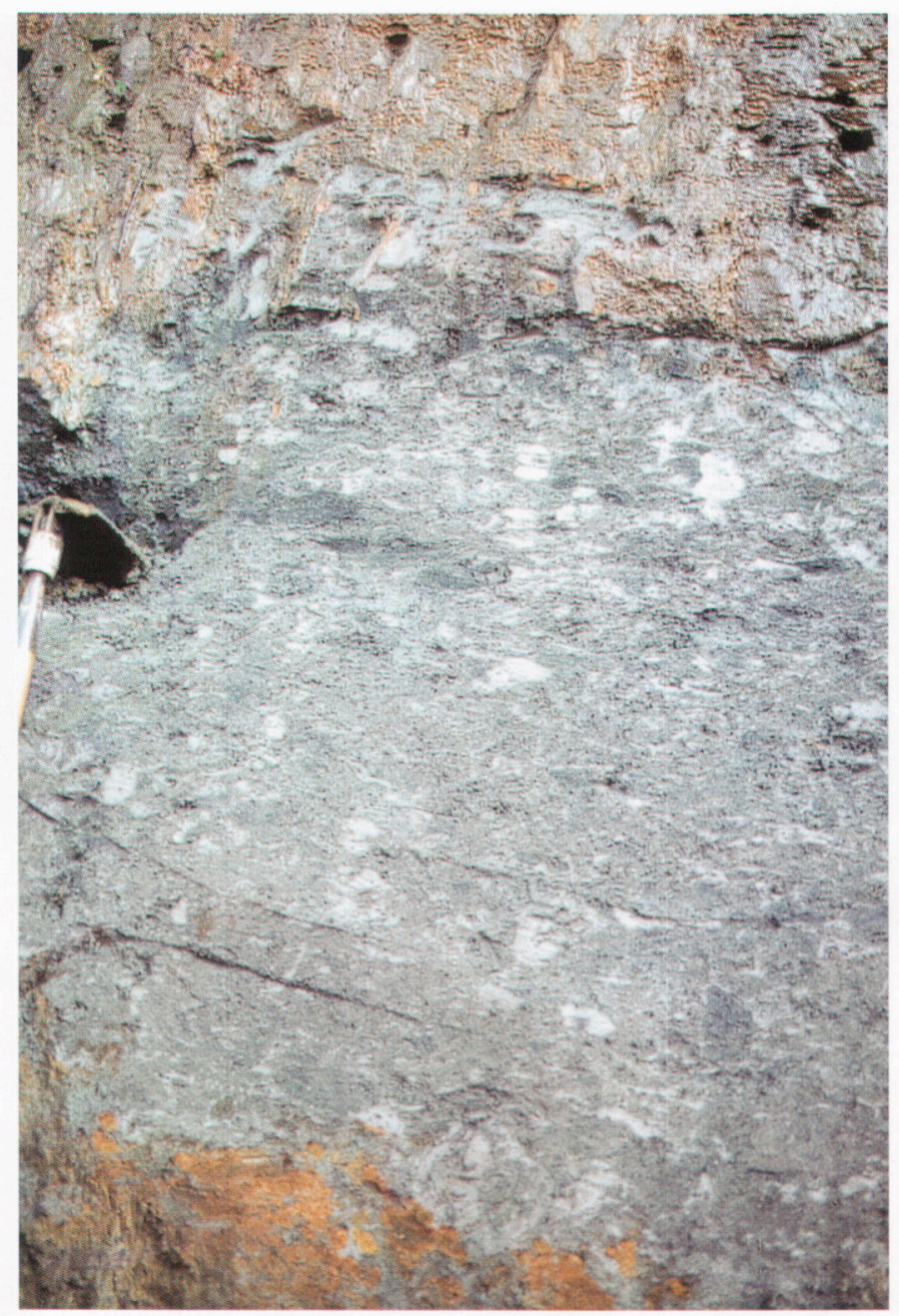

Photograph 3 (left). The typical facies of the sandy clay (unit $3 a$ of Figure 1) showing the pale coloured clay patches and the dark green glauconite filled bioturbations.

Photograph 4 (below). The typical facies of the upper part of the clay unit (unit $3 \mathrm{~b}$ of Figure 1) showing the wavy fine laminated structure of the clay.

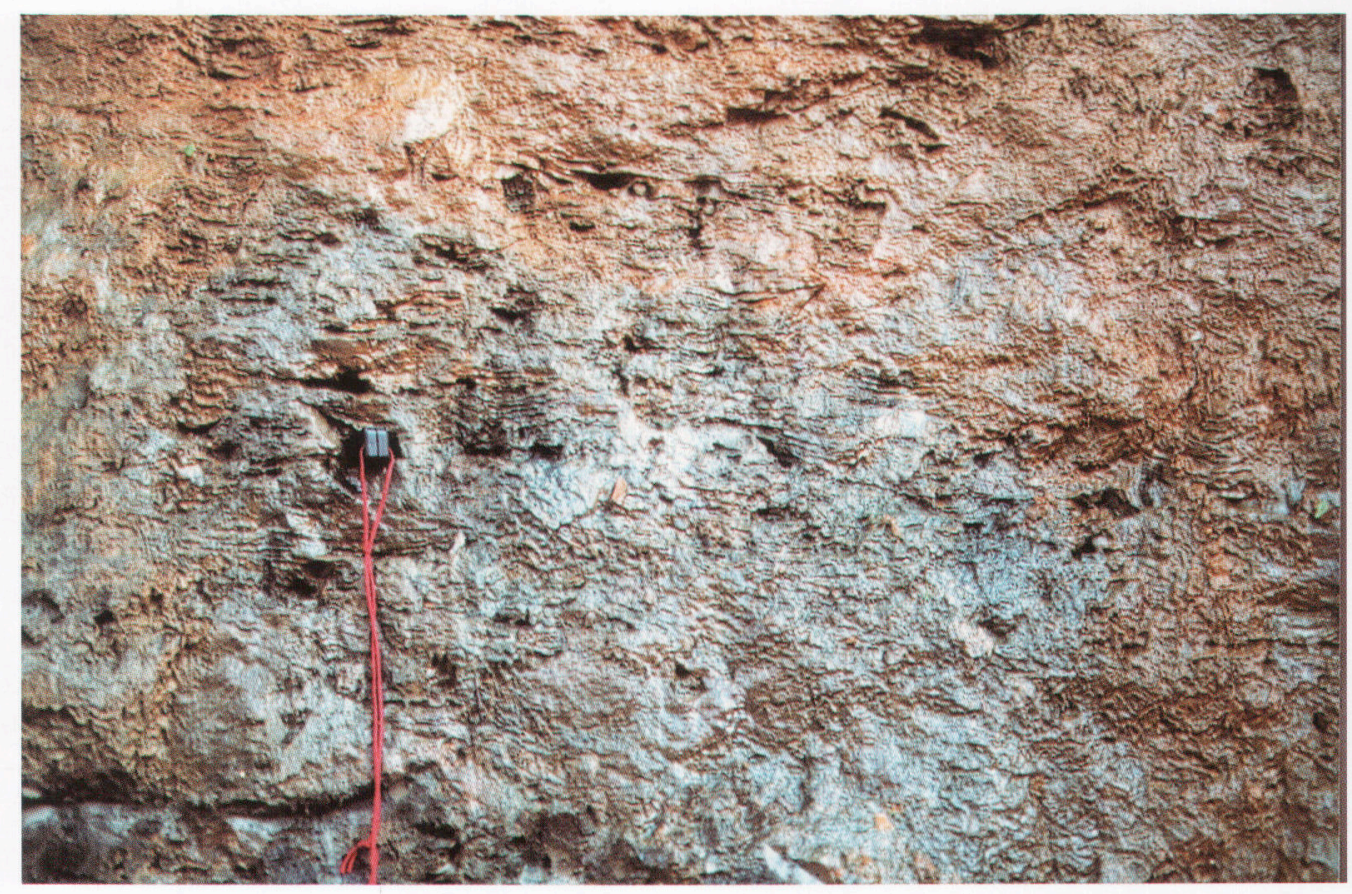


Poederlee Sand in the hills of Poederlee and Lichtaart (Fig.2a) for its fossil mould content. Stratigraphically this level could be correlated with the base of the Merksem Sand, just overlying the Kruisschans Sands and Clay of which it contains some typical reworked molluscs. Merksem and Kruisschans are both members of the Lillo Formation typically developed in the Antwerp harbour area (Fig.5). A lower part of the Poederlee Sand is a geometrical lateral equivalent of a mollusc rich sand wedging out to the east that could be correlated with the Oorderen Sand, another member of the Lillo Formation. We assume that the same regionally occurring iron cemented stone layer with internal fossil moulds is involved in the Grobbendonk site described by Halet (1938) as his layer D overlying the clay unit. Halet (1938) interpreted this sand with ferruginous sandstone and fossils as top Scaldisian (sensu Geol. Legend 1929, see Fig.5), where indeed the stratigraphic position of the Merksem Sand belongs (Fig.5).

If this assumption is correct, it would then bracket the clay unit between the Merksem Sand (Piacenzian) and the Kattendijk Sand (Lower Zanclean). Reworking of the Luchtbal Sands (Middle Zanclean) is known in the area, and also the wedging out of the Oorderen Sand (Lower Piacenzian) has been described (Schiltz et al. 1993; Buffel et al. 2001).

Just underlying the Merksem Sand in the Antwerp area, where the section is most complete, occurs a clayey facies deposited under tidal conditions: the Kruisschans Sand and Clay (de Heinzelin 1962, De Meuter \& Laga 1976) (Fig.5). In exposures of the harbour docks the Kruisschans Member consists of alternating shell bearing glauconite sand layers and pure grey to dark grey clay layers of a few up to 20 centimetre thickness each. The total thickness of this member can be about $3 \mathrm{~m}$. The alternation of the glauconite sands and the pure clay layers together with some erosional features suggest a tidal environment with mudflats. The Kruisschans Member is underlain by a sparse gravel in the Antwerp harbour (de Heinzelin 1962) which together with the tidal flat environment suggests a slightly lower relative sea-level position compared to the overlying Merksem and underlying Oorderen Members. The tidal clay unit in Grobbendonk, assuming the above stratigraphic correlations, occurs at the stratigraphic position of this Kruisschans Member, having also in common the tidal mud flat sedimentary environment.

The molluscs reported from the Kruisschans Member indicate a cooling of the climate (Marquet 1993). Also the Elasmobranchidae fish remnants, of which only the Rajidae are abundant, indicate a cool climate.

\subsection{The pollen diagram of the clay unit}

The pollen assemblages present in the diagram of the 5 samples of the clay unit (location on Fig.1) show very little internal development (Fig. 3). The assemblage is pre-eminently dominated by Pinus pollen (ca 80\%). Among NAP Ericaceae is the most dominant taxa. Only minor traces of warmth loving trees, which are generally grouped into the 'Tertiary Taxa' are present. Of this group Sciadopytis, Tsuga, Cupressacea, Nyssa and Sequoia need to be mentioned. A high representation of these taxa is not to be expected since these Pinus dominated spectra indicate boreal conditions during the deposition of this lithological unit. The low presence of the 'Tertiary Taxa' must be interpreted as being reworked from older deposits.

Peculiar is the absence of Fagus, Carya and Pterocarya. These species are present in the lower Tiglian and in the Reuverian (Piacenzian) of the area. During the Tiglian the relative contribution of Pterocarya to the pollen assemblages increases at the expense of the 'Tertiary Taxa'. Reworking of sediments belonging to the Tiglian would certainly have led to a higher presence of Pterocarya in the samples, confirming an older age for the Grobbendonk clay unit as discussed above. Therefore, based on the pollen analysis, the stratigraphical age of the deposit is somewhere in the Pretiglian (Lower Gelasian), where one or more phases of distinct cooling took place, or it may correspond to a cold phase in the Pliocene. The latter possibility is more probable because on the one hand no marine Pretiglian deposits have ever been found in the area and on the other hand the regional geological analysis above suggests a Pliocene age. It might even confirm the lateral equivalence of the clay unit with the Kruisschans Member, as the Kruisschans fossils point to a cold water influx.

Comparing with the analyses of Hacquaert (1962), the poor representation of Tertiary pollen, the dominance of Pinus and the absence of Taxodinium also suggest that only the Upper Lillo Formation (Kruisschans, Merksem, Zandvliet Members) can be involved and not the Lower Lillo Formation (Oorderen and Luchtbal Members). Hacquaert (1962) refers to Pretiglian analyses by Zagwijn in a well in Kloosterzande in Zeeland and also concludes that the Upper Lillo Formation is Pliocene and not yet Pretiglian. Van Hoorne (1962) also discussed the Pliocene age of the Mol, Merksplas and Merksem sands.

\subsection{Dinoflagellate cysts and other marine palynomorphs of the clay unit}

Two samples (Fig.1) from the tidal clay unit were investigated for marine palynomorphs (Fig. 4). Standard palynological maceration of $75 \mathrm{~g}$ of sediment involved demineralisation with $\mathrm{HCl}$ and $\mathrm{HF}$. No ultrasonic treatment nor acid oxidation were applied in order to avoid damage (loss of pigment, thinning of cyst walls) and selective loss of species. A minimum of 200 specimens were counted per sample. Preservation of the palynomorphs is moderate to poor and the species diversity low since only 


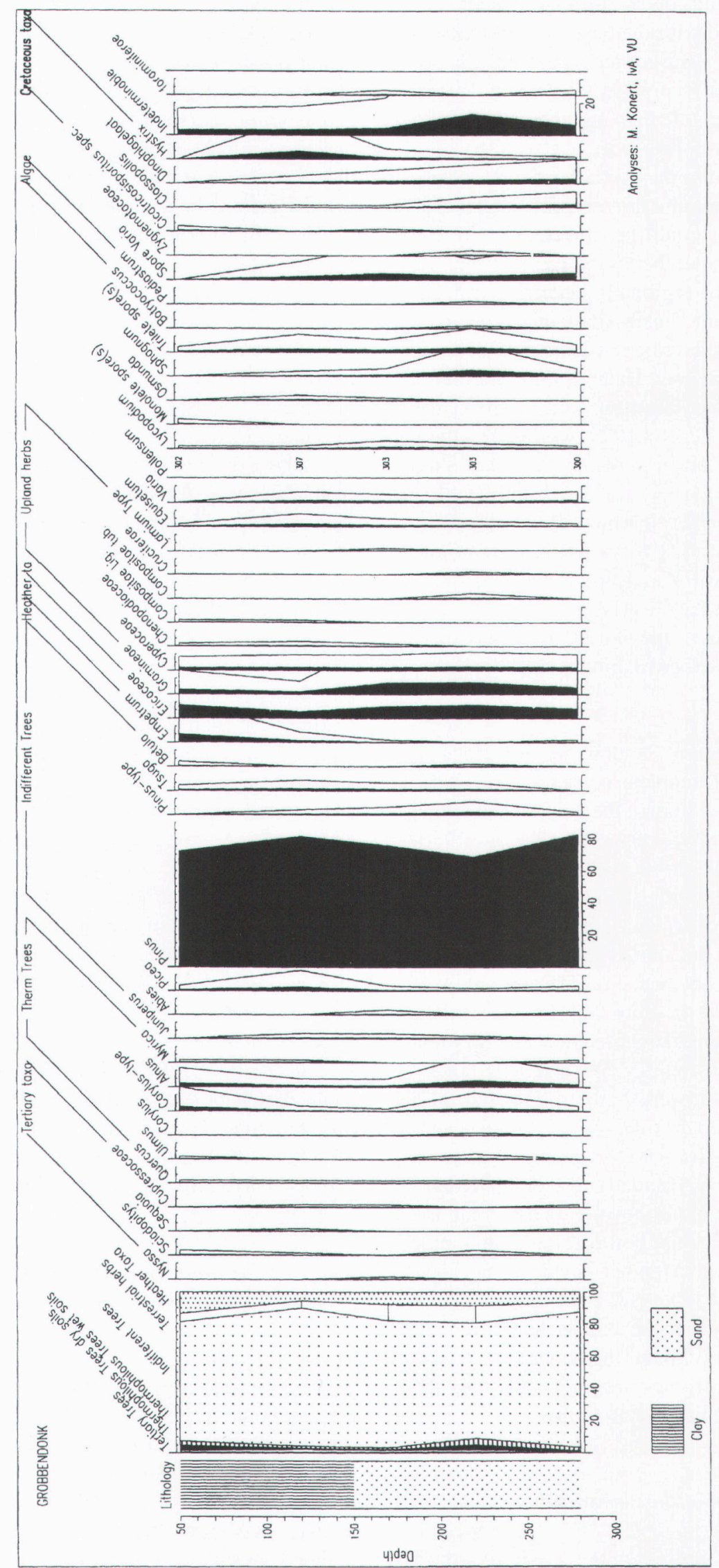




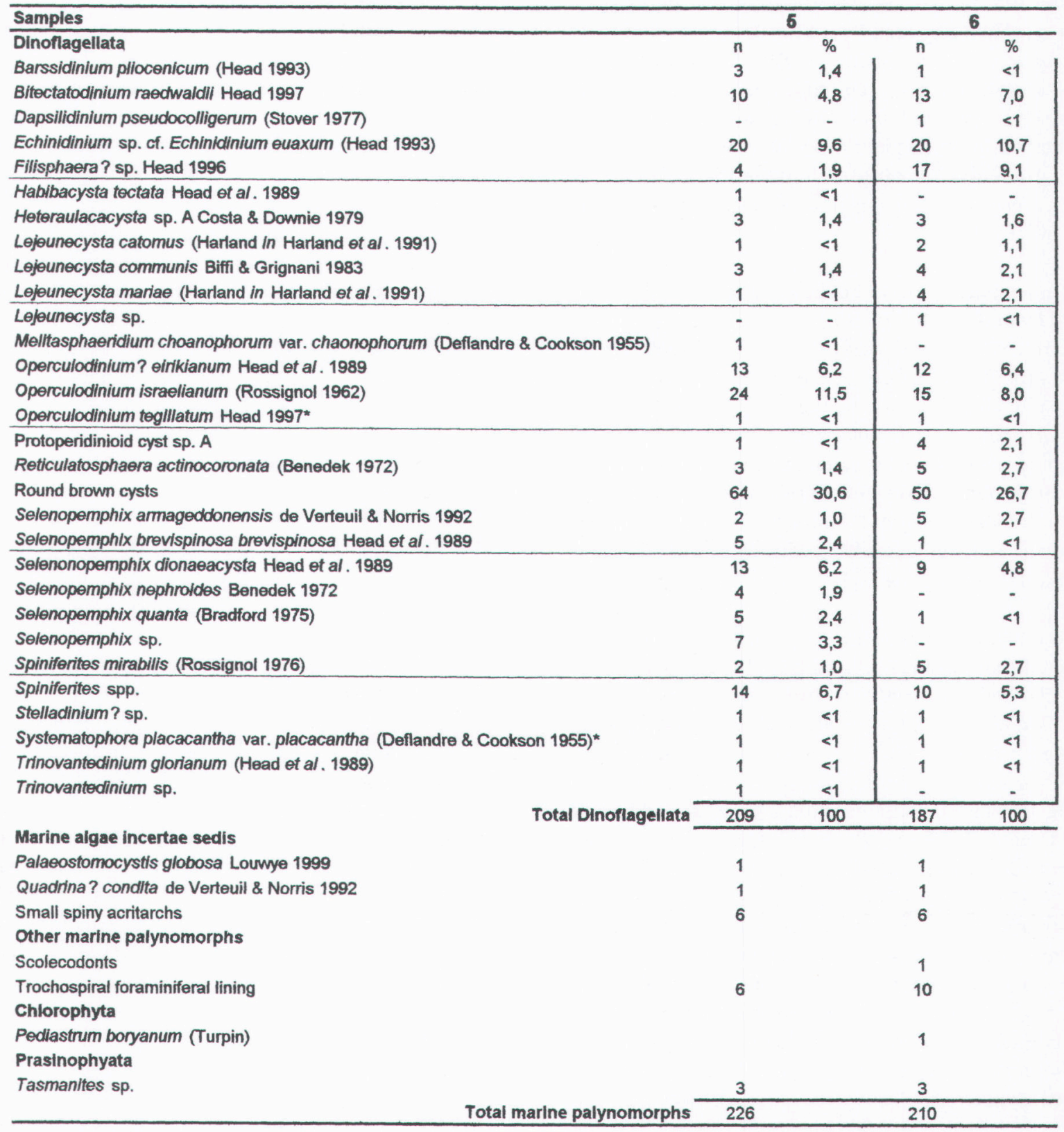

Figure 4. The marine palynomorphs from the Grobbendonk tidal clay (unit 3). For the dinoflagellate cysts, raw count are given together with percentages. Nomenclature is after Williams et al. (1998). An asterisk ${ }^{*}$ ) marks reworked taxa. Sample 5 is the lower sample and sample 6 the upper sample (see sample location on Fig.1). 
a total of 37 marine palynomorph species were recorded. Eight dinoflagellate cyst species dominate $(>5 \%)$ the assemblages in one of the samples: Bitectatodinium raedwaldii, round brown cysts, Echinidinium sp. cf. Echinidinium euaxum, Filisphaera? sp. Head 1996, Operculodinium? eirikianum, Operculodinium israelianum, Selenopemphix dionaeacysta and Spiniferites spp. The other 22 dinoflagellate cyst species each represent less than 5\% of the assemblages (Fig.4). Systematophora placacantha is the only species with a pre-Neogene highest occurrence and can definitely be considered reworked, probably together with some representatives of the undetermined group of Spiniferites spp. The presence of single damaged specimens of Operculodinium tegillatum is most probably also caused by reworking.

The assemblages from Grobbendonk are largely dominated by protoperidinioid cysts, amounting to more than $40 \%$ in each sample. They include round brown cysts, most probably members of the genus Brigantedinium, and species belonging to the genera Barssidinium, Lejeunecysta and Selenopemphix. The presence of high numbers of round brown cysts can be paleo-environmentally important. These protoperidinioid cysts are abundant in modern sediments deposited in shallow marine, eutrophic environments and also in cold waters from high latitudes (polar regions) (Dale, 1996; Mudie \& Harland, 1996).

Head (1998a) reviewed the stratigraphic distribution of selected dinoflagellate cysts in the Pliocene of eastern England and presented their provisional highest occurrences and calibration to the standard time scale of Berggren et al. (1995). The association found in the Grobbendonk tidal clay compares well to the association in the base of the Waltonian Red Crag Formation found by Head (1998b). Barssidinium pliocenicum, Bitectatodinium raedwaldii, Operculodinium? eirikianum, Lejeunecysta mariae, Spiniferites mirabilis, round brown cysts and Operculodinium israelianum are species found in both sequences. Important species, some with a definite oceanic affinity, recorded in the Red Crag but absent in the shallow marine tidal clay of Grobbendonk are Achomosphaera andalousiensis, Geonettia? sp. Head 1997, Impagidinium aculeatum, Nematosphaeropsis lemniscata, Tectatodinium pellitum and especially the cool-tolerant species Bitectatodinium tepikiense. However, Filisphaera? sp. Head 1996, Lejeunecysta catomus and Lejeunecysta communis noted in Grobbendonk are in eastern England only recorded in younger deposits, more specifically in the Pre-Ludhamian by Harland in Harland et al. (1991) and Zalasiewicz et al. (1988), and in the Ludhamian by Head (1996).

Summarising, the dinoflagellate cyst assemblages from the Grobbendonk tidal clay compare well to those recorded in the English Waltonian to Ludhamian deposits, even taking into account that Head (1998a, 1998b) stresses the possibility of a preservational bias in the English Pliocene dinoflagellate cyst associations caused by an in-situ oxidation. Head (1998a) comments on the correlation between the English stages with the standard pollen stages and substages of The Netherlands by Gibbard et al. (1991) and gives the following correlation: Waltonian with Reuverian B at ca 2.7 Ma, PreLudhamian with Praetiglian or Reuverian $\mathrm{C}$ at ca 2.6 to 2.4 Ma, and Ludhamian with Tiglian A 2.3 Ma. The alternative correlation of the Pre-Ludhamian with the Reuverian C is proposed by Head (1998a). The PreLudhamian is interpreted as a cool time between the more temperate Waltonian and Ludhamian.

As the deposits are definitely older than the Tiglian (see above) and as the Waltonian has rather a mild- or warmtemperate climate, the cooler Pre-Ludhamian seems a more appropriate correlation candidate. However the estimated age of the Kruisschans Member is ca $3 \mathrm{Ma}$ (Vandenberghe et al. 1998). An older age seems also excluded as some species found at Grobbendonk are absent from older deposits in England.

\section{Conclusions}

A thin clay unit occurring at the Grobbendonk drinking water extraction site of P.I.D.P.A. between about 5 to 8 m T.A.W. topographic level represents a tidal mud flat deposit within the Upper Lillo Formation. A regional analysis shows it to be probably lateral equivalent of the Kruisschans Member of the Lillo Formation in the Antwerp harbour type area. The Kruisschans Member also is deposited in a tidal mud flat environment. The paleontological content, molluscs in Kruisschans and pollen in the Grobbendonk clay unit, both indicate a cold climatic phase. This cold phase could also explain the slight sea-level drop at this stratigraphic position. Also the dinoflagellates point to a colder climatic interval although the estimated age of that interval is about $0.5 \mathrm{Ma}$ younger than the estimated age of the Kruisschans Sand.

\section{References}

BERGGREN, W.A., KENT, D.V., SWISHER, K.C.C. \& AUBRY, M.-P., 1995. A revised Cenozoic geochronology and chronostratigraphy. In: BERGGREN, W.A., KENT, D.V. \& HARDENBOL, J. (eds.): Geochronology, Time Scales and Global Stratigraphic Correlation. Society for Sedimentary Geology, Special Publication, 54: 129-212.

BUFFEL, P., VANDENBERGHE, N., GOOLAERTS, S. \& LAGA P., 2001. The Pliocene sediments in 4 boreholes in the Turnhout area (North-Belgium): the relationship with the Lillo and Mol Formations. Aardkundige Mededelingen, Leuven University Press, 11: 1-7. 


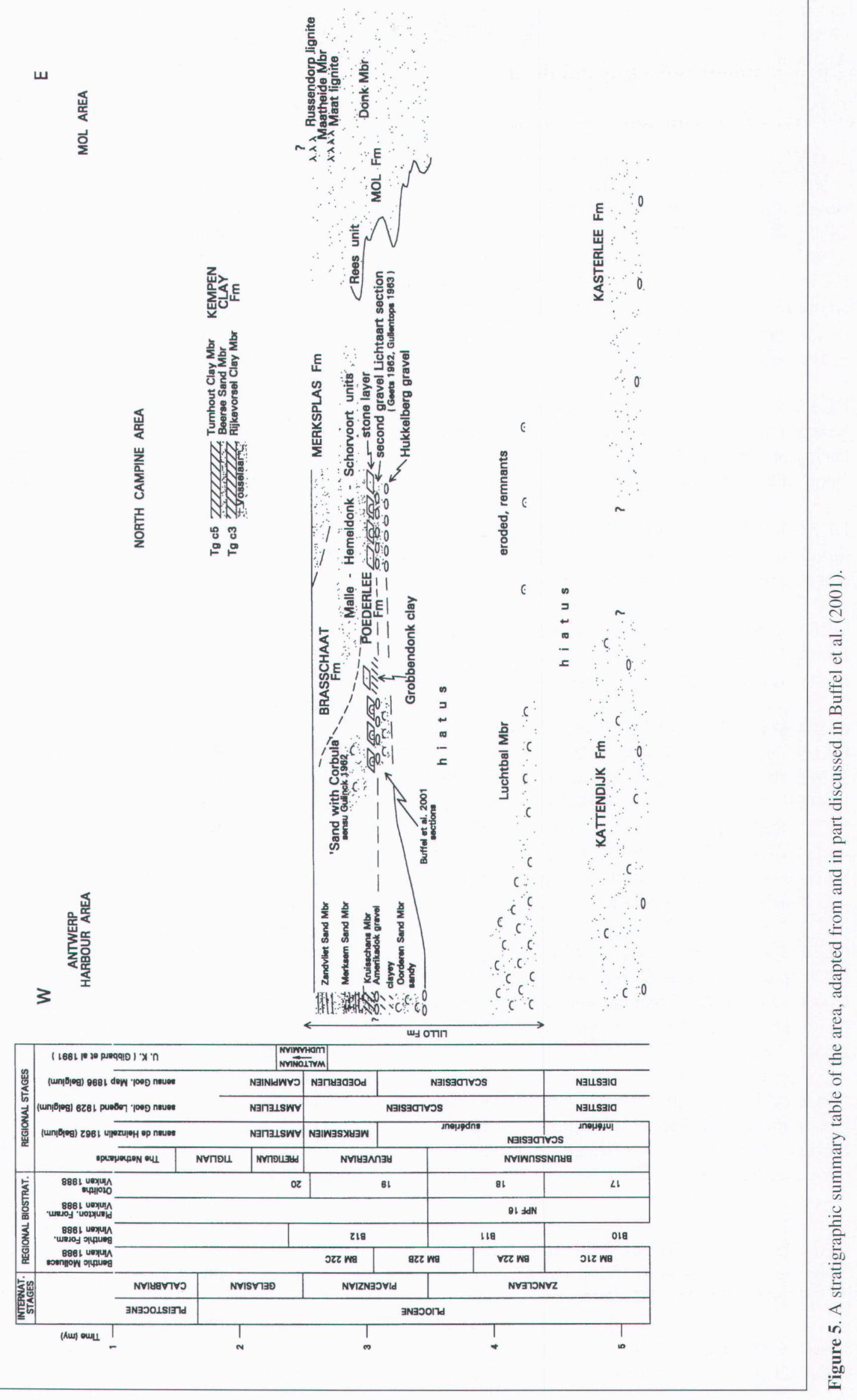


DALE, B., 1996. Dinoflagellate cyst ecology: modelling and geological applications. In: JANSONIUS, J. \& McGREGOR, D.C. (eds.): Palynology: Principles and Applications, American Association of Stratigraphic Palynologists Foundation, Dallas, Texas. Volume 3: 12491275.

de HEINZELIN, J., 1962. Carte et coupe d'ensemble de la région anversoise. Symposium sur la stratigraphie du néogène nordique. Mémoires de la Société belge de Géologie, 6: 247-249.

DE MEUTER, F. \& LAGA, P., 1976. Lithostratigraphy and biostratigraphy based on benthonic foraminifera of the Neogene deposits of Northern Belgium. Bulletin de la Société belge de Géologie, 85: 133-152.

DE RYCKER, K., 1982. Etude par sondages électriques de résistivité et sondages manuels d'un corps sableux dans lea région Grobbendonk-Pulle. Mémoire de licence, Sc. Géol. Min., U.L.Bruxelles.

DE VERTEUIL, L., \& NORRIS, G., 1996. Miocene dinoflagellate stratigraphy and systematics of Maryland and Virginia. Micropaleontology, 42(supplement): 1-82.

GEETS, S., 1962. Stratigrafische positie van het Poederliaan in de Antwerpse Kempen. Natuurwetenschappelijk Tijdschrift, 44: 143-152.

GIBBARD, P.L., WEST, R.G., ZAGWIJN, W.H., BALSON, P.S., BURGER, A.W., FUNNELL, B.M., JEFFERY, D.H., de JONG, J., van KOLFSCHOTEN, T., LISTER, A.M., MEIJER, T., NORTON, P.E.P., PREECE, R.C., ROSE, J., STUART, A.J., WHITEMAN, C.A. \& ZALASIEWICZ, J.A., 1991. Early and early middle Pleistocene correlations in the southern North Sea Basin. Quaternary Science Review, 10: 23-52.

GULINCK, M., 1962. Essai d'une Carte géologique de la Campine. Etat de nos connaissances sur la nature des terrains néogènes recoupés par sondages. Symposium sur la stratigraphie du Néogène nordique. Mémoires de la Société belge de Géologie, 6: 30-39.

HACQUAERT, N., 1962. Etude palynologique des sables marins scaldisiens et merxémiens du Hansadok à Anvers. Symposium sur la stratigraphie du Néogène nordique. Mémoires de la Société belge de Géologie, 6: 96-101.

HALET, F., 1938. Sur les formations Pleistocènes et Néogènes des environs de Grobbendonk. Bulletin de la Société belge de Géologie, 48: 567-576.

HARLAND, R., BONNY, A.P., HUGHES, M.J. \& MORIGI, A.N., 1991. The lower Pleistocene stratigraphy of the Ormesby Borehole, Norfolk, England. Geological Magazine, 128: 647-660.

HEAD, M., 1996. Late Cenozoic dinoflagellates from the Royal Society Borehole at Ludham, Norfolk, Eastern England. Journal of Paleontology, 70(4): 543-570.

HEAD, M.J., 1988a. Marine environmental change in the Pliocene and early Pleistocene of eastern England: the dinoflagellate evidence reviewed. Mededelingen Nederlands Instituut voor Toegepaste Geowetenschappen TNO, 60: 199-226.

HEAD, M.J., 1998b. Pollen and dinoflagellates from the Red Crag at Walton-on-the-Naze, Essex: evidence for a mild climatic phase during the early Late Pliocene of eastern England. Geological Magazine, 135(6): 803-817.

KASSE, K., 1988. Early-Pleistocene tidal and fluviatile environments in the southern Netherlands and northern Belgium. Free University Press Amsterdam.

LAGA, P., 1976. PIDPA cross sections PGL 76/122. Documents Geological Survey of Belgium, Brussels.

LOUWYE, S., DE CONINCK, J. \& VERNIERS, J., 1999. Dinoflagellate cyst stratigraphy and depositional history of Miocene and Lower Pliocene formations in northern Belgium (southern North Sea Basin). Geologie en Mijnbouw, 78: 31-46.

MARQUET, R., 1993. The molluscan fauna of the Kruisschans Member (Lillo Formation, Late Pliocene) in the Antwerp area (Belgium). Contributions to Tertiary and Quaternary Geology, 30(3-4): 83-103.

MUDIE, P.J. \& HARLAND, R., 1996. Aquatic Quaternary. In: JANSONIUS, J. \& McGREGOR, D.C. (eds.): Palynology: Principles and Applications. American Association of Stratigraphic Palynologists Foundation, Dallas, Texas. Volume 2: 843-877.

PAEPE, R. \& VAN HOORNE, R., 1976. The Quaternary of Belgium in its relationship to the stratigraphic legend of the geological map. Mémoires Explicatives des Cartes Géologiques et Minières de Belgique, 18: 38 p.

SCHILTZ, M., VANDENBERGHE, N. \& GULLENTOPS, F., 1993. Geologische kaart van België - Vlaams Gewest: kaartblad Lier (16) 1:50 000, Ministerie van de Vlaamse Gemeenschap, Bestuur Natuurlijke Rijkdommen en Energie \& Ministerie van Economische Zaken, Belgische Geologische Dienst.

TAVERNIER, R. \& DE MOOR, G., 1974. L'évolution du Bassin de l'Escaut. Centenaire de la Société Géologique de Belgique. L'évolution quaternaire des 
bassins fluviaux de la Mer du Nord méridionale. Annales de la Société géologique de Belgique, 94: 159-231.

VANDENBERGHE, J., 1983. Late Weichselian River Dune Formation Grote Nete Valley, Central Belgium. Zeitschrift für Geomorphologie Neue Folge, Suppl.-Bd. 45: 251-263.

VANDENBERGHE, N., LAGA, P., STEURBAUT, E., HARDENBOL, J. \& VAIL, P., 1998. Tertiary sequence stratigraphy at the southern border of the North Sea Basin in Belgium. In: de GRACIANSKY, P.C., HARDENBOL, J., JACQUIN, T. \& VAIL, P. (eds.): Mesozoic and Cenozoic Sequence Stratigraphy of European Basins. SEPM Special Publication, 60: 119-154.

VANHOORNE, R., 1962. La superposition des Sables de Mol et des Argiles de la Campine. Symposium sur la stratigraphie du Néogène nordique. Mémoires de la Société belge de Géologie, 6: 83-95.
VINKEN, R.,ed., 1988. The Northwest European Tertiary Basin. Geologisches Jahrbuch, Reihe A, H. 100, 508 p

WILLIAMS, G.L., LENTIN, J.K. \& FENSOME, R.A., 1998. The Lentin \& Williams index of fossil dinoflagellates, 1998 edition. American Association of Stratigraphic Palynologists Contributions Series, 34: 1-817.

ZALASIEWICZ, J.A., MATHERS, S.J., HUGHES, M.J., GIBBARD, P.L., PEGLAR, S.M., HARLAND, R., NICHOLSON, R.A., BOULTON, G.S., CAMBRIDGE, P. \& WEALTHALL, G.P., 1988. Stratigraphy and palaeoenvironments of the Reds Crag and Norwich Crag formations between Aldeburgh and Sizewell, Suffolk, England. Philosophical Transactions of the Royal Society of London, 322B: 221-272.

Manuscript received on 13.8.2001 and accepted for publication on 10.10.2001. 